\title{
A study of causes of perinatal mortality in tertiary center in Bundelkhand region
}

\author{
Shilpi Srivastava*, Sanjaya Sharma, Sushila Kharkwal, Vidya Chaudhary
}

Department of Obstetrics \& Gynaecology, MLB Medical College, Jhansi, Uttar Pradesh, India

Received: 04 November 2014

Accepted: 10 December 2014

\section{*Correspondence:}

Dr. Shilpi Srivastava,

E-mail: drshilpi30nov@gmail.com

Copyright: (C) the author(s), publisher and licensee Medip Academy. This is an open-access article distributed under the terms of the Creative Commons Attribution Non-Commercial License, which permits unrestricted non-commercial use, distribution, and reproduction in any medium, provided the original work is properly cited.

\begin{abstract}
Background: The distribution of causes of death in population suggests a great potential for prevention. So the aim of study is to evaluate the cause of perinatal death in tertiary center of Bundelkhand region in M.L.B. medical college Jhansi, Uttar Pradesh (India).

Methods: A retrospective study was done over a period of last one year from June 2013 to May 2014, which included total 2691 deliveries out of which 184 perinatal deaths occurred, hence perinatal mortality rate was 68.37 per 1000 birth and causes of perinatal deaths was identified and analysed.

Results: Out of $68.37 \%$ perinatal mortality, majority of perinatal deaths $(54.3 \%)$ occurred due to preterm low birth weight with or without associated other factors, $8.6 \%$ due to congenital anomalies, more than $38 \%$ perinatal death due to maternal factor antepartum haemorrhage, eclampsia, obstructed labour, malpresentation, medical problem in pregnancy.

Conclusions: Early identification of mothers at risk of pregnancy complications through antenatal care screening, teaching pregnant women to recognize signs of pregnancy complications, timely access to obstetric care, monitoring of labour for fetal distress, and proper newborn resuscitation may reduce some of the categories of deaths. There should also be increased awareness among paediatrics and obstetrics about coordinated approach to bring down perinatal mortality.
\end{abstract}

Keywords: Perinatal mortality, Still birth, Retrospective study, Prematurity

\section{INTRODUCTION}

Perinatal mortality is taken as an index of the efficacy of not only antenatal and intranatal care but also of the socioeconomic condition of the community. In developing countries, a gestational age of 28 weeks or a birth weight of $1000 \mathrm{gm}$ is taken as lower cut off for perinatal mortality while in developed countries it is 20 weeks of gestation. World Health Organization (WHO) defines perinatal mortality as deaths occurring during late pregnancy ( $>22$ weeks of gestation), during birth and within seven days after delivery. It is widely used as a health indicator in international comparisons, and within countries and regions to estimate temporal trends.
Globally, approximately 5.9 million perinatal deaths occur annually, of which 3.2 million stillbirths (SB) and 2.7 million Early Neonatal Deaths (END). ${ }^{1}$ The highest burden of perinatal deaths is in developing countries. ${ }^{1}$ More than two third of the stillbirths take place during pregnancy and remaining during course of labour. ${ }^{2}$

Several classification systems of perinatal deaths have been developed. The usefulness of these systems varies considerably due to dissimilarities in recording system and information collected. ${ }^{3}$ Perinatal mortality rate in developing countries is three to five folds higher than that in developed countries. Perinatal mortality rate is most sensitive index of health status of children, quality of maternal and child health service. Perinatal mortality is 
directly related to various high risk maternal factors and diseases on one hand and birth weight gestational age characteristics of new born population on the other hand. ${ }^{1}$ Survival of newborn during $1^{\text {st }}$ week of life is determined by stress of intrauterine life and birth process, as well as adjustment to a new environment nutrition and infections. Therefore early neonatal period is most hazardous period of life. Because of the contribution of perinatal mortality to child mortality the United Nations (UN) in year 2000 made a declaration to include maternal and child mortality reduction as a target in its Millennium Development Goals (MDGs 2011). ${ }^{4}$ Nearly 60\% of perinatal deaths in our country are stillbirths and are preventable. $^{2}$ This study was conducted to find out perinatal mortality rate in tertiary centre of Bundelkhand region and evaluate the causes and risk factors to PNMR.

\section{METHODS}

This study is retrospective study done over a period of last one year from June 2013 to May 2014 in department of obstetrics and gynaecology, Maharani Laxmi Bai medical college Jhansi. All the deliveries took place during this period were studied. Late fetal death and early neonatal death after 28 weeks of gestation to 7 completed days of life were included in the study.

Babies weight less than 1000 gm and below 28 weeks of gestation were excluded. The data was analysed and compared with other studies. The cause of perinatal mortality was determined and effect of maternal age, parity, birth weight, obstetrical complications on PNMR were studied.

\section{RESULTS}

The total number of deliveries during last one year from June 2013 to May 2014 in this study were 2691 and among them 184 were perinatal death hence the PNMR was 68.37 per 1000 births and still birth rate was 47.93 per 1000 birth (Table 1).

Table 1: Perinatal outcome.

\begin{tabular}{|ll|}
\hline Indicator & Outcome \\
\hline Total birth & 2691 \\
\hline Total live birth & 2562 \\
\hline Total perinatal death & 184 \\
\hline Still birth & 129 \\
\hline Early neonatal death & 55 \\
\hline Perinatal mortality rate & 68.37 per 1000 \\
\hline Stillbirth rate & 47.93 per 1000 \\
\hline
\end{tabular}

Majority of patient having still birth were unbooked and belong to lower socioeconomic status and majority of perinatal deaths $(54.3 \%)$ were preterm and low birth weight. Majority of perinatal death occurred in maternal age of 20-30 year. Perinatal mortality was found to be more common in multigravida patients. $8.6 \%$ of perinatal mortality associated with congenital anomalies (like anencephaly, hydrocephalous, omphalocele etc.) (Table 2).

Table 2: Distribution of perinatal death.

\begin{tabular}{|c|c|c|}
\hline \multicolumn{3}{|l|}{ Distribution of perinatal death } \\
\hline \multicolumn{3}{|l|}{ Antenatal check-up } \\
\hline Unbooked & 154 & $83.70 \%$ \\
\hline Booked & 30 & $16.30 \%$ \\
\hline \multicolumn{3}{|l|}{ Age } \\
\hline$<20$ year & 28 & $15.22 \%$ \\
\hline 20-3 year & 134 & $72.83 \%$ \\
\hline$>30$ year & 22 & $11.95 \%$ \\
\hline \multicolumn{3}{|l|}{ Socioeconomic status } \\
\hline Low & 129 & $70.11 \%$ \\
\hline Middle & 42 & $22.83 \%$ \\
\hline High & 13 & $7.06 \%$ \\
\hline \multicolumn{3}{|l|}{ Parity } \\
\hline Primi & 65 & $35.33 \%$ \\
\hline Multi & 119 & $64.67 \%$ \\
\hline \multicolumn{3}{|l|}{ Gestational age } \\
\hline Preterm (28-37 weeks) & 100 & $54.35 \%$ \\
\hline Term (37-42 weeks) & 76 & $41.30 \%$ \\
\hline Post term ( $>42$ weeks) & 8 & $4.35 \%$ \\
\hline Congenital malformations & 16 & $8.69 \%$ \\
\hline \multicolumn{3}{|l|}{ Mode of delivery } \\
\hline Normal vaginal & 104 & $56.52 \%$ \\
\hline Caesarean section & 68 & $36.96 \%$ \\
\hline Instrumental vaginal delivery & 12 & $6.52 \%$ \\
\hline
\end{tabular}

Prematurity is major cause of perinatal mortality. Obstetrical complication associated with perinatal mortality are antepartum haemorrhage $(4.35 \%)$, eclampsia (10.32\%), obstructed labour (8.15\%), malpresentation $(11.96 \%)$, other medical problems like diabetes mellitus, jaundice etc. (Table 3 ).

Table 3: Distribution of perinatal death according to cause.

\begin{tabular}{|lll|} 
Causes & $\begin{array}{l}\text { Number of } \\
\text { perinatal } \\
\text { death }(\mathrm{n}=184)\end{array}$ & $\%$ \\
\hline Prematurity & 51 & $27.72 \%$ \\
\hline Antepartum haemorrhage & 8 & $4.35 \%$ \\
\hline Hypertensive disorder & 19 & $10.33 \%$ \\
\hline Obstructed labour & 15 & $8.15 \%$ \\
\hline Malpresentation & 22 & $11.96 \%$ \\
\hline Intrauterine growth retardation & 7 & $3.80 \%$ \\
\hline Medical problem in pregnancy & 7 & $3.80 \%$ \\
\hline Congenital malformation & 16 & $8.69 \%$ \\
\hline Infection & 10 & $5.43 \%$ \\
\hline Uterus rupture & 4 & $2.17 \%$ \\
\hline Unexplained & 25 & $13.58 \%$ \\
\hline
\end{tabular}




\section{DISCUSSION}

Occurrence of stillbirth pose difficult situation for the obstetrician and cause great psychological and emotional trauma to the couple and the family. It reflects the suboptimum quality of maternal and child health services.

Stillbirth rates vary widely depending on geographic region, socioeconomic condition and also in different regions in the same country. In developed countries it is 5 per 1000 or less, but it is in the range of $30-40$ per 1000 births in underdeveloped countries. ${ }^{5}$

Perinatal mortality rate in this study is 68.37 per 1000 birth and still birth rate 47.93 per 1000 birth. Perinatal mortality rate varies widely from one part to other part. In this study it is more than other studies. ${ }^{7,8,11,12}$ It may be due to illiteracy, low socioeconomic status of Bundelkhand region and due to study has been conducted in tertiary health centre. It is lesser than some studies. ${ }^{6}$

Majority of patients belonged to lower socioeconomic status $70.12 \%$, it is comparable with other studies. ${ }^{5-7,9,11,12}$

The relatively high PNMR is accounted by the fact that the most mothers had one or more high risk factors. It is evident that adequate antenatal care is one of the major requisite in reduction of perinatal mortality. $60 \%$ percent of these patients had high risk factors in the antenatal period like pregnancy induced hypertension, antepartum haemorrhage. Early identification of risk factors and appropriate intervention is important to bring down perinatal mortality.

Perinatal mortality rate in multigravida is relatively higher than primigravida. ${ }^{7,10-13}$

$27.71 \%$ fetal death due to preterm birth and low birth weight, it is comparable to other studies. . $^{6,8,9,11,13,14}$ Preterm babies often died of hypothermia and respiratory distress syndrome. $54.3 \%$ perinatal death is due to prematurity with or without associated other factors. Premature low birth weight babies were however more likely to die during the perinatal period than low birthweight term babies. Term babies would have better immunity and mature respiratory systems with adequate surfactant production and are able to regulate their body temperature and $8.6 \%$ death due to congenital malformation such as anencephaly, multiple congenital anomalies, hydrocephalous, omphalocele and cystic hygroma.

\section{CONCLUSION}

Majority of perinatal deaths are preventable by improving literacy, socioeconomic condition and antenatal checkup.

So it is important to identify high risk factor before pregnancy and during gestation for appropriate care. There should also be increased awareness about risk factor of the stillbirth that can be avoided by proper diet, adequate rest, regular antenatal check-up.

Early detection of high risk factors and their prompt management can save many still births due to placental insufficiency. Modern gadgets like color Doppler, nonstress tests can detect the fetal jeopardy before occurrence of stillbirth.

Carefully performed obstetric ultrasonography \& use of partograph and intrapartum fetal monitoring can detect fetal distress before major damage takes place. Avoidance of prolongation of labour, especially the second stage.

Careful selection of cases for instrumental deliveries and availability of neonatologist for resuscitation of asphyxiated newborn can reduce the rate of stillbirths.

Pediatrician and obstetrician should have co-ordinated approach to bring down perinatal mortality.

Funding: No funding sources

Conflict of interest: None declared

Ethical approval: Not required

\section{REFERENCES}

1. World Health Organization. Neonatal and perinatal mortality. In: WHO, eds. Country, Regional and Global Estimates 2004. WHO Publications Geneva: WHO; 2007.

2. Di Mario S, Say L, Lincetto O. Risk factors for stillbirth in developing countries: a systematic review of the literature. Sex Transm Dis. 2007;34(7 Suppl 1):S11-21.

3. Tanaka S, Stock SJ, Yamamoto Y, Kondejewski J, Olson DM. Understanding perinatal mortality. Obstet Gynaecol Reprod Med. 2010;20:317-22.

4. United Nations. The millennium development goals report 2011. In: UN, eds. UN Report. New York: United Nations; 2011A: 3-67.

5. Mc Clure EM, Nalubamba-Phiri M, Goldenberg RL. Stillbirth in developing countries. Int J Gynaecol Obstet. 2006;94:82-90.

6. Sujata, Das V, Agrawal A. A study of perinatal deaths at a tertiary care teaching hospital. J Obstet Gynaecol India. 2008;58(3):235-8.

7. Korde-Nayak VN, Gaikwad PR. Causes of stillbirth. Obstet Gynaecol India. 2008;58(4):314-8.

8. Shinde A. The study of perinatal mortality in a rural area. J Obstet Gynaecol India. 2001;51(2):77-9.

9. Kulkarni R, Chauhan S, Shah B, Menon G, Puri C. A descriptive observational study investigating causes of perinatal mortality by verbal autopsy in Maharashtra, India. Indian J Community Med. 2007;32(4):259-63.

10. Bellad MB, Srividhya K, Kangle Ranjit, Dhaded SM. Factors associated with perinatal mortality: a 
descriptive observational study. South Asian Federat Obstet Gynaecol. 2010 Jan-Apr;2(1):49-51.

11. Bangal Vidyadhar B, Chandaliya Rajiv M, Pandit Hrishikesh. A review of socio demographic factors and obstetric causes of stillbirths at tertiary care hospital. IOSR J Pharm. 2012 May-Jun;2(3):475-8.

12. Bhattacharya S, Mukhopadhyay G, Mistry PK, Pati S, Saha SP. Stillbirth in a tertiary care referral hospital in North Bengal. Online J Health Allied Sci (OJHAS). 2010 Oct-Dec;9(4):4.

13. McClure EM, Wright LL, Goldenberg RL, Goudar SS, Parida SN, Jehan I, et al. The global network: A prospective study of stillbirths in developing countries. Am J Obstet Gynaecol. 2007;197:247e1-5.

14. Fretts RC. Etiology and prevention of stillbirth. Am J Obstet Gynaecol. 2005;193:1923-35.

DOI: $10.5455 / 2320-1770 . i j \operatorname{rog} 20150208$

Cite this article as: Srivastava $\mathrm{S}$, Sharma S, Kharkwal S, Chaudhary V. A study of causes of perinatal mortality in tertiary center in Bundelkhand region. Int J Reprod Contracept Obstet Gynecol 2015;4:43-6. 